\title{
Research on Integration of Entrepreneurship Education and Professional Education in Colleges and Universities
}

\author{
Qing Mei \\ Jiangsu Vocational Institute of Commerce, Nanjing, Jiangsu, China, 211168
}

Keywords: College Education; Entrepreneurship Education; Professional Education; Integration Analysis

\begin{abstract}
As a new way of cultivating talents, entrepreneurship education has gradually become a hot spot in the reform of education and teaching in colleges and universities, and has strengthened the cultivation of college students' entrepreneurial ability. It aims to cultivate high-quality qualified professional with high level of knowledge and practical ability in line with social needs talent. National education reform outline also clearly pointed out that we should actively promote the work of college education. From the current point of view of promoting the social needs of entrepreneurship education, entrepreneurial talents with a strong professional background, with greater potential for future new entrepreneurs, the integration of entrepreneurship education and professional education can better help college students to achieve professional field of entrepreneurship. Therefore, this paper analyzes the integration value of entrepreneurial education and professional education in colleges and universities, and then expounds the path of the integration of entrepreneurial education and professional education in colleges and universities.
\end{abstract}

\section{Introduction}

The difference between the two is the difference between the internal categories of education. Interrelated, interdependent unity, but also more and more show the trend of integration of the two. As an important educational idea in the current college education, entrepreneurship education has become the value orientation of the education work in colleges and universities. Teachers' active integration of entrepreneurial education concept and related theories in the teaching work of colleges and universities can help the contemporary college students to establish a good sense of entrepreneurship, cultivate a good entrepreneurial spirit, more conducive to the future of college students forward and development.

\section{The Relationship between Entrepreneurship Education and Professional Education}

Entrepreneurship education is a kind of new educational idea put forward by the western countries in the 1970s. It combines research, education and commercial training to cultivate talents with innovative spirit, entrepreneurial consciousness and entrepreneurial ability through simulation exercises. Professional education is divided with the disciplines and social division of labor, in accordance with the disciplines or technical areas, focusing on the teaching of a subject of basic theoretical knowledge and professional skills, so as to cultivate the professional field of specialized personnel [1]. At present, Chinese entrepreneurship education is unreasonable, the goal is not clear, the overall entrepreneurial education effect is not obvious state, colleges and universities after years of development, has formed a professional education, training a large number of specialized personnel, formed a more Perfect professional education system.

There is a clear difference between the two aspects of entrepreneurship education and professional education, but the two are complementary and complementary. The quality of people is with innovative consciousness and practical ability. Professional education is the prerequisite and foundation of entrepreneurship education. Entrepreneurship education is the expansion and deepening of professional education. Higher education, as a higher education, has a general, 
systematic and fundamental education and reform in the background of the times. With the traditional professional education separated, relatively narrow closed state, the formation of mutual communication, a virtuous circle of entrepreneurship education chain [2]. Establish a new model of entrepreneurship education and professional education in line with the needs of economic development and in line with Chinese characteristics.

\section{The Value Analysis of Education and Professional Education Integration}

Entrepreneurship Education and Professional Education Integration Is the Inevitable Trend of the Future Development of Colleges and Universities. "National long-term education reform and development plan" clearly pointed out that adhere to the people-oriented, promote quality education is the development of education reform and development of the strategic theme, focusing on all students, to promote students' all-round development, efforts to improve students to serve the country and the people's social responsibility, the courage to explore the spirit of innovation and good at solving the problem [3]. From the height of educational reform, the innovation and entrepreneurship education as a breakthrough in the comprehensive reform of education, clear the future of college innovation and entrepreneurship education in the overall goal, so in this context, Chinese colleges and universities will be entrepreneurship education and professional education for effective integration, but also the inevitable trend of the future development of colleges and universities, colleges and universities should not only focus on the implementation of professional education, but also a high degree of focus on employment and entrepreneurship education. In the current period, the ultimate goal of teaching reform in our country is to improve the quality of personnel training and cultivate high-quality talents who can adapt to the social and economic development, that is, to cultivate comprehensive talents with both solid professional knowledge and skills, and entrepreneurial spirit and ability, so the current college only entrepreneurship education and professional education for organic integration to achieve the future sustainable development of colleges and universities.

Entrepreneurship Education and Professional Education Integration are the Objective Requirements of the Current Social Development. At present, Chinese higher education is developing in the popular stage, while the state also requires colleges and universities to continue to expand their employment development strategy, and actively promote the concept of entrepreneurship to promote employment, so the current college education entrepreneurship work is definitely not to ease the employment pressure of the expedient. Entrepreneurship education is to focus on the new changes in international talent competition, which is to meet the needs of the new era of challenges, the twenty-first century is an era of innovation and entrepreneurship is one of the important elements of innovation. To realize the great rejuvenation of the Chinese nation in China, we must enter the era of creation, innovation and entrepreneurship, and constantly improve the independent innovation ability of college students in China. Colleges and universities as a training base for high-quality personnel should actively assume this important task to speed up the construction of social and economic development to adapt to personnel training mode.

Entrepreneurship Education and Professional Education Integration is to Achieve the Needs of National Economic Development. At present, Chinese social economy is in a stable stage of development, in this period the country needs more innovative talents, the only way to better enhance the country's overall strength, the current in order to better promote Chinese socio-economic development, We must continue to establish the whole society of the spirit of innovation, training a large number of high-quality innovative talents. And the current establishment of the whole society of the spirit of innovation, to ensure that the main position of enterprise innovation, training innovative talents, the entrepreneurial education as a general, fundamental, systematic education and teaching reform project, as the training of global innovation talent The basic project [4] can better cultivate a group of strong social responsibility, innovation and entrepreneurial ability, and good at innovative achievements into effective productive forces of high-quality professionals, to achieve our social and economic development to provide more talent to support. 


\section{The Path Selection of Education and Professional Education Integration}

Constantly Changing the Educational Philosophy of Colleges and Universities. Education concept is the guide, seeking entrepreneurship education and professional education integration path and strengthen the integration, we must learn from the concept of education to enhance the need for integration between the two start [5]. To truly realize the organic integration of entrepreneurship education and professional education, we should pay attention to the establishment of entrepreneurial education and professional education in one of the educational philosophy, only to establish the integration of the two educational concepts, to be able to truly achieve entrepreneurship education and professional education coordination, thus effectively complete the teaching objectives. Therefore, college teachers should pay attention to constantly enrich their own professional education concept, fully understand the meaning and importance of entrepreneurship education, entrepreneurship education itself is to cultivate more entrepreneurial talent, so that students learn how to adapt to society in school, through Combining Entrepreneurship Education and Professional Education to Train Students' Entrepreneurship and Skills. The professional education in colleges and universities is developed with the continuous development of the profession and the continuous differentiation of the disciplines. It shows the characteristics of practicality and instrumentalism. Professional education can provide good guarantee for students to participate in social practice. Therefore, colleges and universities should deeply understand the relationship between entrepreneurship education and professional education, so as to establish the educational concept of the integration of the two. Only colleges and universities can only establish the educational concept of entrepreneurship education and professional education so as to ensure that students can establish their initiative through the establishment of entrepreneurial education to adapt to the concept of social entrepreneurship and development capabilities.

Continue to Deepen the Teaching Reform of Colleges and Universities. Taking the entrepreneurial education into the personnel training program. Talent training program is the top design of university personnel training, is the principle and direction of personnel training, is the ultimate goal of personnel training, and has a guiding effect on the training of talents in colleges and universities. Many colleges and universities will be innovative and entrepreneurial education as a small part of the entrepreneurial will and entrepreneurial ideas of the training of students, ignoring the innovative entrepreneurship education into the entire personnel training system. Entrepreneurship education is a systematic project, the need for the school top design, full, all-round, the whole process of entrepreneurship education, linkage teaching, employment, student management and other departments to carry out a comprehensive [6]. Colleges and universities to establish a combination of entrepreneurship education and professional education concept, change the educational ideas and concepts, learn from the successful practice of Western developed countries, combined with the objectives of the school personnel training, entrepreneurship education into the professional personnel training program, but also We will focus on the development of entrepreneurial awareness and entrepreneurial talents as the development goals of entrepreneurship education and effectively penetrate into the whole process of future talent training programs in colleges and universities. The education of entrepreneurial talents is an important part of the talent education system in colleges and universities on the Foundation of Entrepreneurship Education in College Professional Education.

Integrate the entrepreneurial education and curriculum system and teaching content. Colleges and universities in order to entrepreneurship education and professional education integration of the concept and understanding, to enhance the college students entrepreneurial ability and quality, the need for curriculum structure and teaching content on the implementation of educational practice. Colleges and universities should pay attention to the professional education process, the effective penetration of entrepreneurship education, and constantly strengthen the work of entrepreneurship education and professional education work in the integration of relevant professionals in the knowledge structure required to build a more comprehensive, scientific and development The curriculum system, better deepen the content of college curriculum teaching. At the same time continue to optimize their own teaching methods and methods to cultivate college students 
entrepreneurial thinking and practical training as soon as possible into the university curriculum, the real sense of entrepreneurship and spiritual training, effective penetration in the professional classroom teaching process, through diversification teaching methods, so that students need to grasp the entrepreneurial thinking and skills, and constantly improve the students find problems, analyze the problem and solve the problem level. In the practice of entrepreneurship education in colleges and universities to strengthen rather than weaken the professional teaching is the right direction, to the traditional re-knowledge transfer, theoretical explanation of the indoctrination into "avant-garde" thinking training, subject connotation of the heuristic teaching [7] The In addition, colleges and universities should also pay attention to the curriculum content in the process of setting up a timely addition of comprehensive teaching courses, the establishment of a number of marginal disciplines and interdisciplinary teaching courses, the real effective expansion of students' knowledge, in the university career guidance courses, effective The addition of entrepreneurial education curriculum knowledge, through this way, continue to increase the students related to entrepreneurial knowledge and skills.

Strengthen the construction of teachers. At present, many college teachers not only focus on entrepreneurship education is not enough, but also the lack of entrepreneurial education practice ability, and colleges and universities have no independent entrepreneurial education teachers. It is the key to realize the integration of entrepreneurship education and professional education [8], which is a combination of expert and dynamic development. Therefore, colleges and universities should pay attention to the construction of the relevant teaching staff, entrepreneurs and teachers to integrate entrepreneurship for the school teachers to actively provide some opportunities for entrepreneurship development of academic exchanges, and actively carry out the relevant theoretical and case studies for the backbone of teachers to provide some Excellent entrepreneurial education opportunities, and actively participate in industry, business practice, through this way, the real business education for colleges and universities to provide a strong practical ability of professional teachers. Therefore, the current colleges and universities in order to make up for the lack of entrepreneurial teachers, you can hire some successful entrepreneurs and technical innovation experts to the school as a visiting professor, to help students accumulate entrepreneurial experience, and better promote the development of college teachers.

Achieve Organic Integration of Entrepreneurship Education Practice Teaching and Professional Education Practice Teaching. At present, there is a phenomenon of separation between classroom learning and classroom practice in innovative entrepreneurship education or in professional education. It is very important to stimulate students' practical interest and encourage students to continue to study in professional courses. Therefore, colleges and universities should pay attention to constantly cultivate the entrepreneurial ability of contemporary college students, and realize the effective integration of entrepreneurship education practice and the existing professional education practice teaching, so as to realize the mutual penetration and promote each other. Colleges and universities should pay attention to combined with professional education resources, based on professional, business and social needs as the center, to create business team, to carry out business training for college students to provide business development projects, but also pay attention to actively carry out diversified extracurricular entrepreneurship practice , To organize and participate in all levels of entrepreneurial competition, to promote the communication between college students entrepreneurship groups, exchanges and cooperation, in addition, to allow entrepreneurship students across the professional elective, the depth of the curriculum integration, will learn all combined with the project to participate competition, the classroom teaching results continue to transform, to enhance students' entrepreneurial awareness and entrepreneurial spirit, at the same time, we also encourage teachers and students to declare the project, or participate in the project guidance. Of course, the content of college entrepreneurship infrastructure is absolutely more than that, just rely on the power of the school is far from enough, but also need to continuously enhance the importance of the whole society, the relevant state departments should pay attention to timely policy support and concessions, only so as to truly realize the organic integration of entrepreneurship education and professional education in colleges and universities. 


\section{Conclusion}

In short, entrepreneurship education and professional education are an important part of the current teaching work in colleges and universities, both in order to cultivate more innovative and capable talents, entrepreneurship education and professional education cannot be replaced, but cannot distinguish, only the two are effective integration to be able to achieve common progress and development. Therefore, the current colleges and universities should focus on the integration of entrepreneurship education and professional education, focusing on the professional education process, the effective penetration of entrepreneurship education, the only way to reinforce the students' professional knowledge, and continuously improve the overall quality of students, real society and business of the quartet common development.

\section{References}

[1] Liu Xiaoting. On the Effective Way of Developing Entrepreneurship Education - Based on the Combination of Entrepreneurship Education and Professional Education

[J]. Chinese University Students Employment, 2014, (02): 19-22 + 38.

[2] Xu Xiaozhou, Zhang Min.Enterprise education concept change and strategic choice [J]. Education Research, 2012,33 (05): 64-68.

[3] Office of the National Medium and Long Term Education Reform and Development Plan Outline Working Group. National Medium and Long Term Education Reform and

Development Plan Outline [N]. People's Daily, 2010-03-01 (005).

[4] Huang Mao. College Entrepreneurship Education and professional education integration development [J]. Education and occupation, 2010, (15): 74-76.

[5] Zhang Yaoxiang, Jiang Lijun. Higher vocational entrepreneurship education and professional education integration path selection [J]. Chinese higher education,

2011, (20): 46-47.

[6] Shao Yuehua.Study on the Effective Integration Path of Innovative Entrepreneurship Education and Professional Education in Higher Vocational Colleges [J]. China Vocational and Technical Education, 2016,10: 76-79.

[7] Qian Jun. University of innovative entrepreneurship education and professional education interactive integration model [J]. Education Exploration, 2016, (11): 84-87.

[8] Jiang Jianjun, Wang Weizhong. The double helix model of entrepreneurship education and professional education [J]. Journal of Zhejiang Wanli University, 2017,02: 1-5.

[9] Du Hui, Zhu Xiaomei. Innovative Entrepreneurship Education and the deep integration of professional education - based on the Beijing University of the data analysis [J]. Chinese University Science and Technology, 2017,05: 91-94. 